\title{
Do Northern Ireland school meals meet English nutrient based standards?
}

\author{
L. E. McGuffin ${ }^{1}$, R. K. Price ${ }^{1}$, S. M. Kelly ${ }^{1}$, T. A. McCaffrey ${ }^{2}$, M. B. E. Livingstone ${ }^{1}$, \\ J. M. W. Wallace ${ }^{\mathrm{and}}$ H. McCarthy \\ ${ }^{1}$ Northern Ireland Centre for Food and Health, University of Ulster, Coleraine, BT52 1SA and ${ }^{2}$ Department of \\ Nutrition and Dietetics, Monash University, Melbourne, VIC 3168, Australia
}

Extensive research on school meal provision in England has led to the implementation of both food based standards (FBS; e.g. 2 portions of fruit and vegetables should be available per child, per day) and nutrient based standards (NBS; e.g. an average school lunch must provide at least $193 \mathrm{mg}$ of calcium). Currently, Northern Ireland (NI) follows only FBS. Therefore, the aim of this research was to evaluate school meal provision in NI in relation to the 14 NBS followed in England.

A random sample of 20 primary and 10 post-primary schools was selected to equally represent schools from each Education and Library Board (ELB), management type (controlled, maintained) and urban/rural locations. All schools provided a menu cycle (1-4 weeks), composite recipe information, preparation methods, cooking methods, ingredient and product information. Saffron (Fretwell-Downing Hospitality Ltd, 2012) was used for the nutritional analysis of menus and the School Food Trust's $\mathrm{NBS}^{(1)}$ were used to evaluate the menus. A Mann Whitney U Test compared the total number of NBS met between different types of schools (primary (PS) vs post-primary (PPS); ELB; management type; urban rural) and data are presented as median $\left(25^{\text {th }}\right.$ and $75^{\text {th }}$ percentiles).

The majority of PS met $11(10,12)$ of the 14 NBS and the majority of PPS met $8(7,9$; Table) with PS being significantly more likely to meet the NBS $(\mathrm{P}<0.001)$ than PPS [9]. No significant differences were seen between school types, such as ELB, management type or urban/rural locations.

\begin{tabular}{|c|c|c|c|c|c|}
\hline Nutrient & $\begin{array}{l}\text { Minimum/ } \\
\text { maximum NBS }\end{array}$ & $\mathrm{NBS}^{1}$ & $\begin{array}{l}\% \text { of Primary schools } \\
\text { meeting NBS }(n 20)\end{array}$ & $\mathrm{NBS}^{1}$ & $\begin{array}{l}\% \text { of Post-primary school } \\
\text { meeting NBS }(n 10)\end{array}$ \\
\hline Energy (kJ) & Range & $2104-2326$ & 45 ( $30 \%$ above; $25 \%$ below) & $5665-2835$ & $20(80 \%$ below $)$ \\
\hline Carbohydrate (g) & Min & 70.6 & 80 & 86.1 & 30 \\
\hline NMES (g) & $\operatorname{Max}$ & 15.5 & 80 & 18.9 & 90 \\
\hline Fat $(\mathrm{g})$ & $\operatorname{Max}$ & 20.6 & 95 & 25.1 & 100 \\
\hline Saturated fat $(\mathrm{g})$ & Max & 6.5 & 85 & 7.9 & 80 \\
\hline Protein $(\mathrm{g})$ & Min & 7.5 & 100 & 13.3 & 100 \\
\hline Fibre $(\mathrm{g})$ & Min & 4.2 & 100 & 5.2 & 100 \\
\hline Sodium (mg) & $\operatorname{Max}$ & 499 & 0 & 714 & 20 \\
\hline Vitamin A $(\mu \mathrm{g})$ & Min & 175 & 100 & 245 & 80 \\
\hline Vitamin C (mg) & Min & 10.5 & 100 & 14 & 100 \\
\hline Folate $(\mu \mathrm{g})$ & Min & 53 & 100 & 70 & 90 \\
\hline Calcium (mg) & Min & 193 & 100 & 350 & 0 \\
\hline Iron (mg) & Min & 3 & 30 & 5.2 & 0 \\
\hline Zinc (mg) & Min & 2.5 & 95 & 3.3 & 0 \\
\hline
\end{tabular}

The present results have highlighted energy and key nutrients (carbohydrate, sodium, calcium, iron and zinc) that currently do not conform to the School Food Trust's NBS. These findings are consistent with previous research in England [e.g. $\left.{ }^{(2,3)}\right]$ and highlight that more targeted strategies to address these 'problem nutrients' may be required by school meal providers in NI.

1. School Food Trust, 2009. At: http://www.schoolfoodtrust.org.uk/the-standards/the-nutrient-based-standards/guides-and-reports/guide-to-thenutrient-based-standards.

2. Nicholas J, Wood L, Harper C, Nelson M (2013) Public Health Nutrition 16(06), 1052-65.

3. Stevens L, Nicholas J, Wood L, Nelson M (2013) Public Health Nutrition 16(06), 1037-42. 